\title{
Evaluation of the use of raw extract of Euphorbia tirucalli $L$. in the healing process of skin wounds in mice ${ }^{1}$
}

\author{
Euler Nicolau Sauaia Filho', Orlando José dos Santos"I, Allan Kardec Duailibe Barros Filho ${ }^{\mathrm{III}}$, Altieres de Arruda Rocha ${ }^{\mathrm{IV}}$, Rafael \\ Campos Silvav, Rayan Haquim Pinheiro Santos ${ }^{\mathrm{VI}}$, Rennan Abud Pinheiro Santos ${ }^{\mathrm{VII}}$

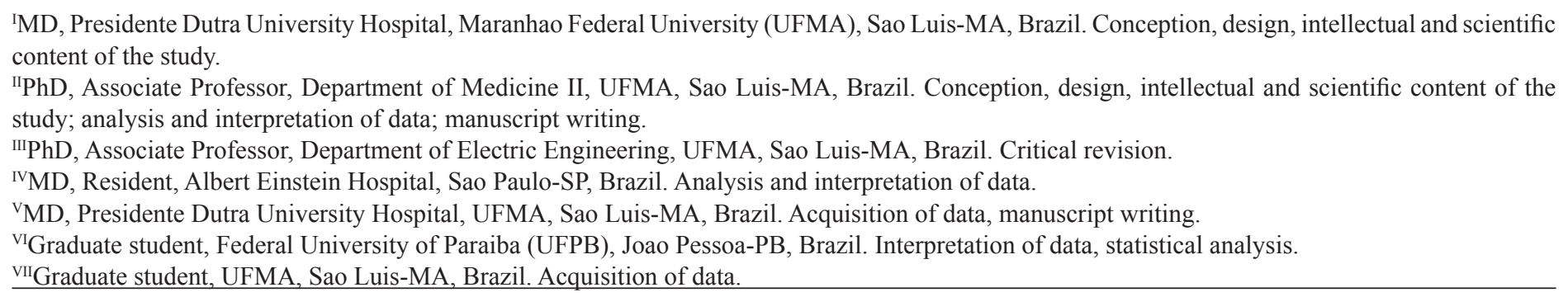

\begin{abstract}
PURPOSE: To evaluate the effects of crude extract of Euphorbia tirucalli in cutaneous wound healing.

METHODS: A total of 20 Swiss mice were randomly divided into two groups, aveloz (GA) and control (CG), and each group was further divided into two subgroups based on the deaths scheduled for the 7th and 14th days after surgery. The animals underwent a resection of cutaneous fragment with $1 \mathrm{~cm}$ in diameter on the dorsum; the GA was applied in each animal on the subsequent days, $0.1 \mathrm{~mL}(30 \mathrm{mg} / \mathrm{mL})$ hydroalcoholic extract of Euphorbia tirucalli was applied on the wound, while the same volume of $0.9 \%$ saline solution was applied to the GC. It was evaluated the lesion diameter and after programmed death, a surgical specimen was resected for histopathology.

RESULTS: In the macroscopic analysis, no statistically significant difference was observed $(\mathrm{p}=0.120$ and $\mathrm{p}=0.186$, for the 7 th and 14th days of death, respectively). The histological evaluation revealed no statistically significant difference in the variables acute inflammation $(\mathrm{p}=0.014)$ and fibrosis $(\mathrm{p}=0.018)$, when compared the group aveloz with the control group on day 14 .
\end{abstract}

CONCLUSION: The crude hydroalcoholic extract of Euphorbia tirucalli L. demonstrated better outcomes in the healing process, acute inflammation and fibrosis on the 14 day postoperatively.

Key words: Phytotherapy. Wound Healing. Euphorbia. Mice. 


\section{Introduction}

The phytotherapy potential for use in medicine has been highlighted in the scientific community interested in finding new substances that can stimulate surgical repair. However, it is still incipient the works with scientifically structured methodology. Most publications are empirical testing based on popular saying ${ }^{1}$.

Brazil has the largest diversified forest reserve in the planet. Many of these species used for medicinal purposes are consumed with little or no scientific evidence of its pharmacological properties, both in rural and urban regions ${ }^{2}$.

In recent years, there has been verified the appreciation of popular practices or unscientific, including the slow reintroduction of medicinal herbs as alternative or complementary therapy. Several herbal remedies have been tested and used in the healing of skin wounds that proved promising. Other natural or synthetic substances, topical and internal use, have been widely studied with the aim of helping the healing process ${ }^{3-10}$.

Euphorbia tirucalli L. [Euphorbiaceae] is known in Brazil as" aveloz". The latex of E. tirucalli has been used by native people as traditional medicine as anti-helminthic, antisiphilitic and anti-tumoral ${ }^{11-14}$

Some biological properties of E tirucalli have been confirmed such as larvicidal, mollucide, bactericidal and antiherpes activities ${ }^{15-19}$. These activities are likely related to the presence of phytosterols and triterpenes ${ }^{12}$.

The study aims at evaluating the topical use of the crude extract of E. tirucalli on the wound healing in mouse skin, emphasizing the macroscopic and histological aspects.

\section{Methods}

The project was evaluated and approved by the by the Ethics Committee in Research at the Federal University of Maranhao (UFMA), protocol no 23115 008767/2008-40. The study followed the guidelines for animal research as set out by the Brazilian College of Animal Experimentation (COBEA).

The sample consisted of 20 male Swiss mice (Swiss webster, Rodentia Mammalia), supplied by the UFMA vivarium. It was between 40 and 60 days old (46 days mean age). The weight was between $24 \mathrm{~g}$ and $30 \mathrm{~g}$ ( $25.3 \mathrm{~g}$ mean weight). They were kept in groups of five per standard cage for the species at the Research Laboratory of the Physiology Department where the light-dark cycle was 12 hours and humidity was the same as a normal environment without any artificial regulation. The temperature was constant at $20 \pm 2^{\circ} \mathrm{C}$. The animals were fed on standard commercial food and had free access to water throughout the experiment.

The animals were randomly divided into two groups of ten (10) mice: control group (CG) and Group Aveloz (GA). These groups were redistributed into two subgroups of five animals and denominated subgroup CG7 and CG14 and subgroup GA7 and GA14 according to the days of death (7th and 14th postoperative days), respectively.

Each animal was subjected to anesthesia with 2\% xylazine hydrochloride $(5 \mathrm{mg} / \mathrm{kg} \mathrm{MI})\left(\mathrm{Kensol}^{\circledR}\right)$ and 5\% ketamine hydrochloride $\left(22 \mathrm{mg} / \mathrm{kg}\right.$, IM) $\left(\right.$ Vetanarcol $\left.^{\circledR}\right)$ combined in the same $^{\circ}$ syringe.

After anesthesia, each mouse was placed in the prone position, immobilized on an operative board and submitted to trichiasis in the dorsal region in the area of $6 \mathrm{~cm}^{2}$. For demarcating the skin to be withdrawn, a metallic punch with cutting blade on its lower edge was used to remove a circular skin fragment with $1 \mathrm{~cm}$ in diameter on the back of the animal. After surgery and recovery from anesthesia, each animal was placed in cage with free access to food and water, kept at the same preoperatively conditions of temperature and brightness. They were evaluated clinically every day.

In the Group Aveloz was performed the dripping procedure using a 1mL-insulin syringe by applying $0.1 \mathrm{~mL}$ of crude extract of Euphorbia tirucalli L. after 24 hours and performing one daily application continuously in the morning at the same time on subsequent days until the eve of the death of the animals. Regarding the animals in the control group, $0.9 \%$ saline solution was administered by dripping using the same volume, time and frequency as the Aveloz Group.

The animals were killed by a lethal dose of $2 \%$ xylazine $(20 \mathrm{mg} / \mathrm{kg}, \mathrm{IM})$ and $5 \%$ ketamine hydrochloride $(30 \mathrm{mg} / \mathrm{kg}$, IM) in the predetermined days of death for each subgroup.

A stereoscope microscope with 2.5-fold magnification was used to determine the largest diameter of the wound and its macroscopic features. The wound was measured at the largest diameter with a digital caliper graduated in millimeters. Data were recorded daily in form protocol for comparison.

After macroscopic assessment, the surgical specimen resection was performed in diameter $2 \mathrm{~cm}^{2}$, including lesion in the center by means of surgical scissors. The samples were placed in individual vials containing $10 \%$ formalin and submitted for histological analysis.

The slides were analyzed under a tetraocular microscope by the same pathologist. The histological field was evaluated using the objective lens of 5, 10 and $x 40$ and ocular of $x 10$ of magnification. 
The histological criteria included: acute inflammation, chronic inflammation, fibroblast proliferation, collagen deposition, wound repithelialization and vascular neoformation. Variables were classified according to intensity (mild, moderate or severe) following the scale of crosses ( $\mathrm{x}$ to +++ )

The software Biostat 5.0 (Microsoft), the Student $t$ test and Mann-Whitney test were used for data analysis at the significance $\mathrm{p}<0.05$.

\section{Results}

Regarding the clinical observation of the animals, there was no difference in the evaluation days between groups (Control Group and Group Aveloz). Animals evolved with good diet acceptance, absence of wound infection and showed no significant changes in body weight.

Wound diameter analysis was based primarily on the diameter obtained at the last check; the comparison was intergroup between the subgroups with the same date of death of the animals. A comparison of Control with Aveloz subgroups with death of the animals in seven days (CG7 and GA7) showed $p=0.120$, while the study on day 14 (CG14 and GA14), showed $p=0.186$, not statistically significant. Wound diameter averages on the last day of each group are shown in Figure 1.

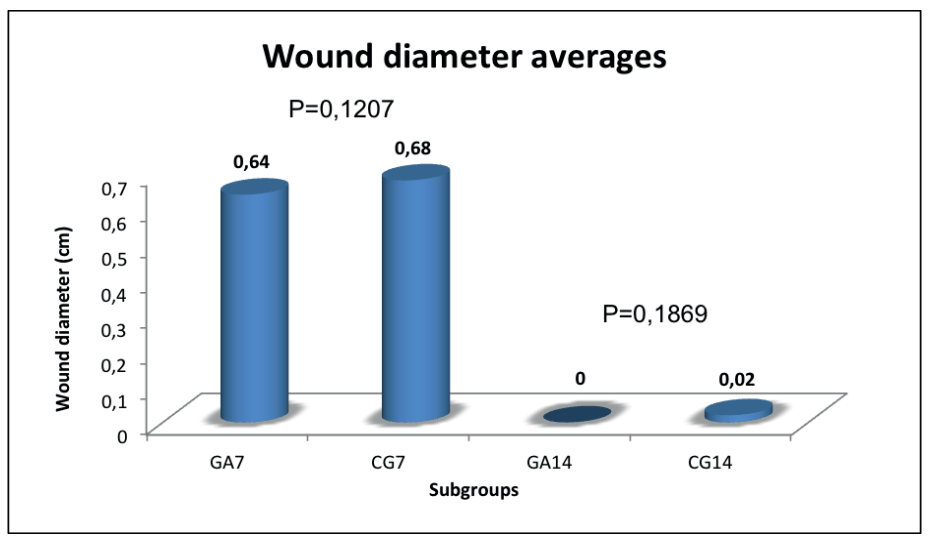

FIGURE 1 - Wound diameter averages $(\mathrm{cm})$ on the last day of each group.

Statistical analysis of these data was performed using the Student $t$ test.

The histopathological results are presented in Tables 1 and 2 .
TABLE 1 - Histological evaluation (acute inflammation, chronic inflammation, fibroblast proliferation and fibrosis) of skin healing parameters in animals treated with raw extract of Euphorbia tirucalli and control (0.9\% saline solution).

\begin{tabular}{|c|c|c|c|c|}
\hline \multirow{3}{*}{$\begin{array}{c}\text { Histological } \\
\text { variables } \\
\text { / p }\end{array}$} & \multicolumn{4}{|c|}{ Days / Groups } \\
\hline & \multicolumn{2}{|c|}{7 Days } & \multicolumn{2}{|c|}{14 Days } \\
\hline & Aveloz & Control & Aveloz & Control \\
\hline Acute & $++(5)$ & $++(5)$ & $\begin{array}{l}-(3) \\
+(2)\end{array}$ & $\begin{array}{l}+(4) \\
++(1)\end{array}$ \\
\hline$/ \mathbf{p}$ & \multicolumn{2}{|c|}{$>0.05$} & \multicolumn{2}{|c|}{$0.014 *$} \\
\hline \multirow{2}{*}{$\begin{array}{c}\text { Chronic } \\
\text { inflammation } \\
/ \mathbf{p}\end{array}$} & $++(5)$ & $++(5)$ & $+(5)$ & $+(5)$ \\
\hline & \multicolumn{2}{|c|}{$>0.05$} & \multicolumn{2}{|c|}{$>0.05$} \\
\hline \multirow{2}{*}{$\begin{array}{c}\text { Fibroblast } \\
\text { proliferation } \\
\text { / p }\end{array}$} & $++(5)$ & $++(5)$ & $++(5)$ & $\begin{array}{c}+(1) \\
++(4)\end{array}$ \\
\hline & \multicolumn{2}{|c|}{$>0.05$} & \multicolumn{2}{|c|}{$>0.05$} \\
\hline \multirow{2}{*}{$\begin{array}{c}\text { Fibrosis } \\
/ / \mathbf{p}\end{array}$} & $+(5)$ & $+(5)$ & $++(5)$ & $\begin{array}{l}+(4) \\
++(1)\end{array}$ \\
\hline & \multicolumn{2}{|c|}{$>0.05$} & \multicolumn{2}{|c|}{$0.018 *$} \\
\hline
\end{tabular}

Variables were classified as absent $(-)$, discreet $(+)$, moderate $(++)$ or severe $(+++)$, based on the relative intensity of acute inflammation, chronic inflammation, fibroblast proliferation and fibrosis. The number in parentheses is the number of animals in each classification. *Implies statistical significance $(\mathrm{p}<0.05)$ 
TABLE 2 - Histological evaluation (angiogenesis and reepithelialization) of skin healing parameters in animals treated with raw extract of Euphorbia tirucalli and control (0.9\% saline solution).

\begin{tabular}{|c|c|c|c|c|}
\hline \multirow{3}{*}{$\begin{array}{c}\text { Histological } \\
\text { variables } \\
\text { / p }\end{array}$} & \multicolumn{4}{|c|}{ Days / Groups } \\
\hline & \multicolumn{2}{|c|}{7 Days } & \multicolumn{2}{|c|}{14 Days } \\
\hline & Aveloz & Control & Aveloz & Control \\
\hline \multirow{2}{*}{$\begin{array}{c}\text { Angiogenesis } \\
\qquad / \mathbf{p}\end{array}$} & $++(5)$ & $++(5)$ & $+(5)$ & $\begin{array}{l}+(3) \\
++(2)\end{array}$ \\
\hline & \multicolumn{2}{|c|}{$>0.05$} & \multicolumn{2}{|c|}{$>0.05$} \\
\hline \multirow{2}{*}{$\begin{array}{c}\text { Reepithelialization } \\
\text { / p }\end{array}$} & $+(5)$ & $+(5)$ & $++(5)$ & $++(5)$ \\
\hline & \multicolumn{2}{|c|}{$>0.05$} & \multicolumn{2}{|c|}{$>0.05$} \\
\hline
\end{tabular}

Variables were classified as absent $(-)$, discreet $(+)$, moderate $(++)$ or severe $(+++)$, based on the relative intensity of angiogenesis. For reepithelialization were used absent $(-)$, partial $(+)$ and complete $(++)$. The number in parentheses is the number of animals in each classification.

Using the Mann-Whitney test, justified by the classificatory character of variables, the histopathological subgroups of CG14 and GA14 showed statistical significant difference in favor of aveloz in acute inflammation and fibrosis, with $\mathrm{p}=0.014$ and $\mathrm{p}=0.018$ respectively. The other variables were not statistically significant in both groups.

\section{Discussion}

Euphorbia tirucalli L., focus of this study, has numerous applications already confirmed by experimental studies, such as the anti-bacterial, anti-herpes and anti-mutagenic effects ${ }^{13,17,18}$. The healing potential of this plant is based on reports from other studies, coupled with the fact of the existence of other species of the same family with the same effect, such as Jatopha gossypiifolia L. .

The skin was the organ chosen for the study due to the great need to discover new pro-regenerative/healing elements with clinical application, since the increase in human life expectancy fostered therapeutic movements that contribute positively in driving chronic diseases such as diabetes mellitus, peripheral vascular disease, prothrombotic situations and neuropathies.

Moreover, other authors have described the use of other herbal medicines in healing $\operatorname{skin}^{7,9,20-22}$.
The route of choice for the extract application was based on the ease in performing the daily administration once most agents with pro-healing function used, now currently in the clinical environment, being topic action and aimed at avoiding greater interference and increased toxicity with respect to the intermediate metabolism of the animal if chosen oral or parenteral administration.

The schedule of days for induction of animals deaths (seven and 14 days postoperatively) was proposed aiming at giving this work a greater comparative capacity with other studies, basing on the stages of repair-healing process (especially in the first two weeks), in contrast with some studies such as Dornelles et $a .^{23}$, that investigated the healing potential of aloe (Aloe vera) in skin wounds in rabbits, observing them for 34 days and Nitz, who used the mastruz (Coronopus didymus), observed the animals until the 7 th day ${ }^{24}$.

The forms of assessment, both macroscopic as microscopic, aimed at characterizing the possible differences generated by the extract application. Since the daily measurement of the diameter of the lesion was the most concrete and pragmatic way to jointly undertake a clinical and mathematical assessment on the wound development, which concurs with other studies in the scientific literature ${ }^{25}$.

Histology was performed to increase the power of inference about the repair started, thus using hematoxylin-eosin (HE) in preparation of the slides, method also chosen by Nitz in the morphometric study on cutaneous wound healing in rats using Coronopus didymus and Calendula officinalis. However, Lucena et $a l .{ }^{25}$, to assess the action of aroreira (Schinus terebinthifolius Raddi) in the healing of surgical wounds in rats bladder, used the Masson trichrome (used to better demonstrate collagen deposition) in addition to $\mathrm{HE}$ for histological examination, this staining technique was also used by Martins et al. ${ }^{8}$ for the comparative analysis of skin healing with the intraperitoneal use of Orbignya phalerata aqueous extract in rats and by Santos et al. ${ }^{9}$ in evaluating the use of crude extract of Jatropha gossypiifolia L. in the healing of skin wounds in rats ${ }^{24}$.

A process of fibrosis better established and with a greater degree of organization was found in the group Aveloz compared to the control group (scheduled for death on the 14th day after surgery), although not statistically significant had been the increased fibroblast cell mass. This infers that the crude extract of Euphorbia tirucalli has stimulatory properties on the collagen secretion without promoting, however, the migratory or replicator activity of fibroblasts. These positive results with regard to healing have also been observed in other studies with plants of the tropics, 
such as mastic, calendula, babassu, mastruz and pião-roxo ${ }^{8,9,23,25}$.

\section{Conclusion}

The use of crude extract of Euphorbia tirucalli L. compared to the control showed no difference in the macroscopic appearance; however, the histological evaluation at 14 days postoperatively showed comparative improvement in the healing of Group Aveloz.

\section{References}

1. Malafaia O, Campos ACL, Torres O, Goldenberg S. Os fitoterápicos e seu potencial na cicatrização em cirurgia. Acta Cir. Bras. 2006;21(Supl 3):1.

2. Bergami-Santos PC, Mariano M, Barbuto JAM. Dual role of polymorphonuclear neutrophils on the growth of Ehrlich ascites tumor (EAT) in mice. Life Sci. 2004;75(2):245-55.

3. Adewunmi C, Adesogan E. Toxicology of some Nigerian Plants used in schistosomiasis control. I. The effect of molluscicides on molluscan hearts. Fitoterapia. 1986;57(5):353-8.

4. Biondo-Simões MLP, Adur RC, Marques LO, Lima EJB, Rosario MAK. Açúcar e ácido acexâmico na cicatrização de feridas cutâneas em ratos. Acta Cir Bras. 1993;(8):83- 6.

5. Santos O, Marques G, Sauaia Filho E, Frota G, Santos R, Santos R. Use of 2-octyl cyanoacrylate adhesive in rat liver induced lesion. Acta Cir Bras. 2012;27(9):624-9.

6. Eurides D. Morfologia e morfometria da reparação tecidual de feridas cutâneas de camundongos tratadas com solução de barbatimão (Stryphynodendron barbatiman martius). Rev Fac Zootec Vet Agro Uruguaiana. 1996;2/3(1):35-40.

7. Garros IC, Campos AC, Tâmbara EM, Tenório SB, Torres OJ, Agulham MA, Araújo AC, Santis-Isolan PM, Oliveira RM, Arruda EC. Extract from Passiflora edulis on the healing of open wounds in rats: morphometric and histological study. Acta Cir Bras. 2006;21:55-65.

8. Martins NLP, Malafaia O, Ribas-Filho JM, Heibel M, Baldez RN, Vasconcelos PR, Moreira H, Mazza M, Nassif PA, Wallbach TZ. Healing process in cutaneous surgical wounds in rats under the influence of Orbignya phalerata aqueous extract. Acta Cir Bras. 2006;21:66-75.

9. Santos MFS, Czeczko NG, Nassif PA, Ribas-Filho JM, Alencar BL, Malafaia O, Ribas CA, Trautwein VM, Henriques GS, Maia JM, Bittencourt RC. Evaluation of the use of raw extract of Jatropha gossypiifolia L. in the healing process of skin wounds in rats. Acta Cir Bras. 2006;21:2-7.

10. Santos O, Barros-Filho A, Malafaia O, Ribas-Filho J, Santos R, Santos R. Schinus terebinthifolius Raddi (Anacardiaceae) in the healing process of. Arq Bras Cir Dig. 2012;25(3):140-6.

11. Hecker E. Co-carcinogenic principles from seed oil of Croton tiglium and other Euphorbiaceae. Cancer Res. 1968;28:2338-49.

12. Khan A, Ahmed Z, Kazml N, Malik A. Further Triterpenes from the Stem Bark of Euphorbia tirucalli. Planta Med. 1987;53(6):577.

13. Rezende J, Rodrigues S, Jabor I, Pamphile J, Rocha C. Efeito antimutagênico do látex de Euphorbia tirucalli no sistema metionina em Aspergillus nidulans. Acta Scientiarum. 2004;26(4):481-4.

14. Silva AC, de Faria DE, Borges NB, de Souza IA, Peters VM, Guerra Mde O. Toxicological screening of Euphorbia tirucalli L.: developmental toxicity studies in rats. J Ethnopharmacol.
2007;110(1):154-9.

15. Tiwari S, Singh P, Singh A. Toxicity of Euphorbia tirucalli Plant Against Freshwater Target and Non- target Organisms. Pak J Biol Sci. 2003;6(16):1423-9.

16. Jurberg P, Cabral Neto JB, Schall VT. Molluscicide activity of the "Avelós" plant (Euphorbia tirucalli, L.) on Biomphalaria glabrata, the mollusc vector of schistosomiasis. Memórias do Instituto Oswaldo Cruz. 1985;80:423-7.

17. Betancur-Galvis LA, Morales GE, Forero JE, Roldan J. Cytotoxic and antiviral activities of colombian medicinal plant extracts of the Euphorbia genus. Memórias do Instituto Oswaldo Cruz. 2002;97:541-6.

18. Lirio LG, Hermano ML, Fontanilla MQ. Antibacterial activity of medicinal plants from the Philippines. Pharm Biol. 1998;36(5):3579.

19. Fürstenberger G, Hecker E. On the active principles of the Euphorbiaceae, XII. Highly unsaturated irritant diterpene esters from Euphorbia tirucalli originating from Madagascar. J Natural Products. 1986;49(3):386-97.

20. Branco Neto ML, Ribas Filho JM, Malafaia O, Oliveira Filho MA, Czeczko NG, Aoki S, Cunha R, Fonseca VR, Teixeira HM, Aguiar LR. Evaluation of hydroalcoholic extract of Aroeira (Shinus Terebinthifolius Raddi) in the healing process of wound skin in rats. Acta Cir Bras. 2006;21:17-22.

21. Amorim E, Matias JEF, Coelho JCU, Campos ACL, Stahlke Jr HJ, Timi JRR, Rocha LC, Moreira AT, Rispoli DZ, Ferreira LM. Topic use of aqueous extract of Orbignya phalerata (babassu) in rats: analysis of it's healing effect. Acta Cir Bras. 2006;21:67-76.

22. Lai HY, Lim YY, Kim KH. Potential dermal wound healing agent in Blechnum orientale Linn. BMC Complement Altern Med. 2011;11:62.

23. Dorneles D, Wouk A, Pontarolo R, Oliveira A. Efeito de Aloe vera Linné sobre a cicatrização de feridas de pele em coelhos. Visão Acad. 2003;4(1):39-46.

24. Nitz A. Estudo morfométrico na cicatrização de feridas cutâneas em ratos, utilizando Coronopus didynus e Calendula officinali. ACM Arq Catarin Med. 2006;35(4):74-9.

25. Lucena PL, Ribas Filho JM, Mazza M, Czeczko NG, Dietz UA, Correa Neto MA, Henriques GS, Santos OJ, Ceschin AP, Thiele ES. Evaluation of the aroreira (Schinus terebinthifolius Raddi) in the healing process of surgical incision in the bladder of rats. Acta Cir Bras. 2006;21:46-51.

\section{Correspondence:}

Orlando José dos Santos

Universidade Federal do Maranhão

Departamento de Medicina II

Avenida dos Portugueses, $\mathrm{s} / \mathrm{n}$

65085-580 São Luís - MA Brasil

orlanddojs@hotmail.com

Received: June 18, 2013

Review: Aug 14, 2013

Accepted: Sept 16, 2013

Conflict of interest: none

Financial source: none

${ }^{1}$ Research performed at Experimental Surgery Laboratory, Federal University of Maranhao (UFMA), Sao Luis, Brazil. 